\title{
The Song Will Survive... An Anthology of Poems About Jews Under the German Occupation (Pieśń ujdzie cało... Antologia wierszy o Żydach pod okupacją niemiecką)
}

Author/editor: Michał M. Borwicz (Boruchowicz)

First Published: 1947

About the Author: Michał Borwicz (1911-1987) was a Polish writer of Jewish origin. He graduated from the Jagiellonian University in Cracow, and in his twenties joined the Polish Socialist Party (PPS). During World War II, he was imprisoned in the Janowska camp in Lviv and conducted underground activity there, which - after escaping the camp with the help of his PPS colleagues - he continued in the Home Army (Armia Krajowa) hiding his Jewish identity. After the war, he chaired the Cracow chapter of the Jewish Historical Commission and published texts written by Jews and Poles during the Holocaust, including his own poems. He also wrote on the cultural life of the camps, the resistance movement, and the situation of Jews after the Holocaust, especially the issue of antisemitism. Due to the increasingly repressive measures of the Communist regime, he immigrated to France in 1947, where he would spend the rest of his life collecting and studying literary works and other writings from the Holocaust period. He defended his doctoral dissertation on this subject at the Sorbonne in 1953.

Further Important Publications: Miłość i rasa (1938, Love and Race; novel); Ze śmiercia na ty (Bruderschaft with the Death, 1946; poems).

\section{Content and Interpretation}

The anthology features poems by Jewish and Polish authors, both famous and lesserknown. As Borwicz himself emphasised, his intention was not to collect the most celebrated poems and authors, but to bring together the whole gamut of Jewish experiences and problems during the war. And so, in addition to his own works, the anthology includes poems by Roman Bratny, Władysław Broniewski ( $\rightarrow$ Selected Poetry), Adela Fruchtman, Mordche Gebirtig, Zuzanna Ginczanka, Janka Hescheles, Mieczysław Jastrun ( $\rightarrow$ A Human Matter), Ila and Henia Karmel, Henryka Łazartówna, Czesław Miłosz ( $\rightarrow$ Selected Poetry), Halina Nelken, Stefania Neyken, Tadeusz Różewicz ( $\rightarrow$ An Excursion to the Museum), Henryk Safrin, Władysław Szlengel $(\rightarrow$ What I Read to the Dead), Julian Tuwim ( $\rightarrow$ We, Polish Jews), Helena Wielowieyska, Rysia Weinreb, and Witold Zechenter, as well as various texts by anonymous authors. Borwicz stresses that he was less interested in artistic criteria than a certain testimonial quality vis-à-vis the wartime period - a way of writing that signals a change in thinking about literature in times of crisis. It is at such times, he points out, that writing tends towards approximations - towards "the closest words" - which is to say,

Ә Open Access. ( 2021 Beata Przymuszata, published by De Gruyter. (c))BY-NC-ND This work is licensed under a Creative Commons Attribution-NonCommercial-NoDerivatives 4.0 License.

https://doi.org/10.1515/9783110671056-096 
well-known phrases and forms that best facilitate communication with the recipient. Borwicz's idea of reading literary works in the sociological and psychological context was an innovation at the time, defined recently by Polish literary researcher Piotr Mitzner as "the law of Borwicz". The immediate reception of Borwicz's work on the Holocaust would suggest that such an approach was ahead of its time; the anthology was considered to be a collection of texts without greater artistic value. In his introduction to the book, Borwicz builds an argument about the power of creativity in times of crisis - namely, that it plays a role in building psychological resistance. He goes on to explain how literary accounts tend to omit much of what happened during the war, largely due to Nazi efforts to obliterate the facts of the occupation, but also because of a general lack of knowledge about everyday life at that time. The Song Will Survive... thus plays an important role in documenting those experiences, from the loneliness faced by Jews in hiding to the fear of denouncement by one's neighbours, and from the persecution of Jews by the German occupiers to Polish indifference towards their fate, or even approval of the degradation of Jewish lives and systematic theft of their property. These and other topics can be found in poems by Władysław Szlengel ( $\rightarrow$ What I Read to the Dead), Mieczysław Jastrun ( $\rightarrow$ A Human Matter), Hadassy Estera Weiss, Gebirtig Mordche, and Czesław Miłosz ( $\rightarrow$ Selected Poetry). In a separate section, the anthology presents accounts of the pogrom in Kielce. These texts are of particular importance as they illustrate how the Holocaust continued after the war (Przymuszała, 2019).

\section{Main Topics and Problems}

The anthology presents a cross section of wartime Jewish experience, from the perspective not only of life in the ghettos, but also of those in hiding, and of those deported to the camps. It shows the perspective of children as well as adults, of Jews as well as Poles, and of those who chose to rise up against the occupiers as well as those just trying to survive. Particularly noteworthy are the texts belonging to thematic cycles, such as the selection of poems by Władysław Szlengel (his collection $\rightarrow$ What I Read to the Dead survived the war, while Szlengel himself died during the Warsaw Ghetto Uprising), and texts by Stefania Ney (Stefania Grodzieńska) on the topic of children living in the ghetto. There are also larger selections from such works as Bruderschaft with Death (Ze śmiercią na ty) by Michał Borwicz, Ghetto Dirges (Pieśni żałobne getta) by Izabela Gelbard (under the pseudonym Czajka), and The Guarded Hour (Godzina strzeżona) by Mieczysław Jastrun, as well as his Human Matter. Szlengel's poems present the most extensive history of everyday life during the Holocaust, speaking to the experience of absolute loneliness but also the strength of those trapped behind the ghetto wall. His poems also highlight the contrasting experiences of Jews and Poles living under similar circumstances, deprived of elementary things that they need to survive or that they plan to trade in exchange for "Aryan papers". In The Guardian's Key (Klucz u stróża), Szlengel recalls seeing a Pole dressed in his own fur coat, a story that serves as an example of the way, in the new order, Poles were 
able to enrich themselves at the expense of their Jewish neighbours. Equally important are texts that speak to uniquely Jewish experiences: Conversation With a Child, for instance, where a mother does not know how to present the picture of normal life to her child who has grown up in the ghetto. Szlengel also illustrates the reality of everyday death. In Monument, for example, a father returns with his son to an empty flat after an action in which his wife was taken: an empty pot around which they focused their shared life (literally and metaphorically) becomes her "monument" and also a sign of her absence. The texts of lesser-known authors also deserve our attention: Two Jewish Women, Five of Them (Dwie żydówki, ich pięcioro) by Hadessa Estera Weiss, for example, tells the heart-wrenching story of Jewish women who wander the streets in search of shelter, and about the girls handed over to the mayor. To Mummy (Bełżec) by eleven-year-old poet Janka Hescheles describes the fear, anxiety, loneliness, and despair of life in the camps with an immediacy that can still be difficult to read. Some texts present the Jewish fate from the point of view of the guilt-ridden outsider: well-known poems such as A Poor Christian Looks at the Ghetto and Campo dei Fiori by Czesław Miłosz ( $\rightarrow$ Selected Poetry), for example, but also a poem by Stanisław Marczak-Oborski dedicated to the memory of Zuzanna Ginczanka, Warsaw in April 1943, in which he grieves "Here is the dying man / for whom I was not a brother". In the final bitter lines of the poem the lyrical subject justifies the hatred that dying ghetto inhabitants may feel towards him, since he remains outside the ghetto walls - perhaps one of the strongest confessions of guilt in poetry.

\section{Cited Works}

Przymuszała, B. (2019). Smugi Zagłady - książki przeoczone. Borwicz i inni. Poznań: Wydawnictwo Naukowe UAM.

\section{Further References}

Adamczyk-Garbowska, M. (2013). Polish literature on the Holocaust. In: A. Rosen, ed., Literature of the Holocaust. Cambridge: Cambridge University Press. Gross, N. (1993). Poeci i Szoa. Sosnowiec: OFFMAX, pp. 10-11. Hensel, J. (2000). Ofiary i świadkowie. Wiersze czasu wojny jako źródło wiedzy o Zagładzie. In: A. Brodzka-Wald, D. Krawczyńska, J. Leociak, eds., Literatura polska wobec Zagłady. Warszawa: Żydowski Instytut Historyczny. Instytut Naukowo-Badawczy, pp. 51 -70. Kobylarz, R. (2009). Walka o pamięć. Polityczne aspekty obchodów rocznicy powstania $w$ getcie warszawskim 1944-1989. Warsawa: Instytut Pamięci Narodowej. Komisja Ścigania Zbrodni przeciwko Narodowi Polskiemu. Löw, R. (2000). Uwagi do przyszłej historii literatury (polskiej) o Zagładzie. In: A. Brodzka-Wald, D. Krawczyńska, J. Leociak, eds., Literatura polska wobec Zagłady. Warszawa: Żydowski Instytut Historyczny. Instytut NaukowoBadawczy, pp. 71-87. Lyon-Caen, J. (2017). Michał Borwicz: między Polską a Francją, między literaturą a historią. Zagłada Żydów. Studia i Materiały, 13, pp. 261-274. Maciejewska, I., ed. (1988). Męczeństwo i zagłada Żydów w zapisach literatury polskiej. Warszawa: Krajowa Agencja Wydawnicza. Miłosz, C., (1983). The Witness of Poetry. Cam- 
bridge: Harvard University Press. Morawiec, A. (2009). Literatura w lagrze. Lager w literaturze. Fakt - temat - metafora. Łódź: Wydawnictwo Akademii HumanistycznoEkonomicznej. Neuger, L. (1997). Żydzi w powojennej poezji polskiej. In: L. Neuger, Pomysty do interpretacji. Studia i szkice o literaturze polskiej. Kraków: Oficyna Literacka.

BP 